\title{
PENGARUH PERMAINAN TRADISIONAL ENGKLEK TERHADAP PENINGKATAN KEMAMPUAN LOMPAT JAUH TANPA AWALAN PADA SISWA KELAS 5 SDN 1 BUNGTIANG TAHUN 2017/2018
}

\author{
Muhammad Hijir Ismail ${ }^{1}$, L. Erpan Suryadi ${ }^{2}$, Rina Nopiana ${ }^{3}$ \\ email: hijirdo@yahoo.com ${ }^{1}$, Rfunlalu66@gmail.com ${ }^{2}$, nopianar@gmail.com ${ }^{3}$ \\ Program Studi Pendidikan Jasmani Kesehatan \& Rekreasi, Fakultas Ilmu Pendidikan, \\ Universitas Hamzanwadi ${ }^{1,2,3}$
}

\begin{abstract}
Abstrak
Penelitian ini bertujuan mengetahui pengaruh permainan tradisional Engkelek terhadap peningkatan kemampuan lompat jauh tanpa awalan pada siswa kelas 5 SDN 1 Bungtiang Tahun 2017/2018. Jenis penelitian yang digunakan dalam penelitian ini adalah eksperimen dengan rancangan penelitian One-Group Pretest-Posttest Desigen. Teknik pengumpulan data menggunakan tes lompat jauh. kemudian dianalisis menggunanakan uji-t. Hasil penelitian menunjukkan bahwa nilai t hitung sebesar $(4,553>1,729)$ yang berarti Ho di tolak dan $\mathrm{Ha}$ di terima sehingga dapat di simpulkan bahwa ada pengaruh Permainan Tradisional Engkelek terhadap Peningkatan Kemampuan Lompat Jauh tanpa Awalan pada Siswa Kelas 5 SDN 1 Bungtiang Tahun 2017/2018.
\end{abstract}

Kata kunci: Permainan tradisional engklek, lompat jauh tanpa awalan

\begin{abstract}
This study aims to determine the influence of Engkelek's traditional game on improving long jump skills without the square off to the studennts of 5th grade on SDN 1 Bungtiang 2017/2018. The type of research used in this study is an experiment with the OneGroup Pretest-Posttest Desigen research. Data collection techniques use the long jump test, then analyzed using $t$-test. The results showed that the calculated $t$ value was $(4,553>1,729)$ which meant that Ho was rejected and Ha was accepted so that it could be concluded that there was an influence of Engkelek Traditional Game on the Long Jump Ability Improvement without the square off to the studennts of 5 th grade on SDN 1 Bungtiang 2017/2018.
\end{abstract}

Keywords: Traditional games engklek, long jump without prefix

\section{A. Pendahuluan}

Indonesia merupakan negara kepulauan yang memiliki keaneka ragaman budaya dan tradisi. Begitu pula dengan keaneka ragaman permainan-permainan tradisional yang telah ada sejak jaman nenek moyang. Disetiap daerah memiliki permainan tradisional yang berbeda-beda antara satu wilayah dengan wilayah lainnya yang disebabkan oleh perbedaan kultur dan kondisi wilayah serta lingkungan dimasing - masing daerah. Walaupun terdapat jenis permainan yang sama antara satu wilayah dengan wilayah yang lain, pastinya nama permainan itu berbeda. Sperti yang kita lihat didaerah kita sendiri di lombok timur banyak sekali perbedaan nama dalam permainan tradisional engklek ini. Adapun nama-nama permainan engkelek dari berbagai kecamatan yang ada di lombok timur ini yaitu: kecamatan terara (permainan dengkelak), kecamatan peringgasela (permainan rempak), kecamatan suralaga (permainan ontong ontong), kecamatan aik mel, (permainan perempak), kecamatan peringga baya (permainan dedengkak), kecamatan sakra (permainan daprak), kecamatan sikur (permainan dengkelak) kecamatan keruak (tengkak demperak), kecamatan labuan 
(permainan rempak). Akan tetapi walaupun berbeda-beda bahasa tetapi cara memainkan nya tetap sama. Permainan tradisional adalah proses melakukan kegiatan yang menyenangkan hati anak dengan mempergunakan alat sederhana sesuai dengan keadaan dan merupakan hasil penggalian budaya setempat menurut gagasan dan ajaran turun-temurun dari nenek moyang. Tidak semua permainan tradisional dapat diangkat menjadi bahan pelajaran pendidikan jasmani di sekolah. Ada beberapa permainan yang layak disajikan sebagai bahan pelajaran pendidikan jasmani.

\section{B. Metode}

Penelitian ini dilaksanakan selama satu bulan dengan melibatkan siswa kelas 5 SDN 1 Bungtiang tahun 2017/2018 menentukan sampel dengan menggunakan sampel jenuh, populasi yang digunakan yaitu keseluruhan siswa kelas 5 SDN 1 Bungtiang tahun 2017/2018 dan rancangan penelitian yang digunakan mengambil data pre test sebelum diberikan treatment dan mengambil data pos tes setelah treatment selesai, pengumpulan data menggunakan tes lompat jauh, hasl dari pre test dan pos tes dianalisis menggunakan uji-t untuk menentukan t-hitung dan t-tabel untuk mengetahui ada tidaknya pengaruh permainan tradisional engklek terhadap peningkatan kemampuan lompat jauh tanpa awalan pada siswa kelas 5 SDN 1 Bungtiang tahun 2017/2018. Adapun langkah-langkah yang dilakukan dalam penelitian ini adalah sebagai berikut: (1) Langkah awal yang dilakukan dalam penelitian ini adalah mempersiapkan persyaratan-persyaratan serta alat-alat yang sekiranya akan menunjang jalannya pelaksanaan penelitian ini. Adapun persyaratan-persyaratan yang peneliti siapkan adalah sebagai berikut: Meminta surat izin penelitian di Fakultas Keguruan dan Ilmu Pendidikan (FIP) Universitas hamzanwadi dengan tujuan ke BAPEDA, (2) Rekomendasi dari kantor BAPEDA diserahkan ke sekolah yang bersangkutan tempat peneliti mengambil data. Dalam penelitian ini, peneliti menggunakan jenis penelitian yang digunakan dalam penelitian ini adalah penelitian eksperimen dan menggunakan sampling jenuh. Adapun subyek penelitiannya semua siswa kelas 5 SDN 1 Bungtiang. selanjutnya peneliti melakukan tes untuk mendapatkan data pree-test dan post-test yaitu tes lompat jauh dengan 3 kali percobaan.

\section{Hasil dan Pembahasan}

Hasil penelitian data pretest dan posttest lompat jauh siswa kelas 5 SDN 1 Bungtiang. Kecamatan sakra barat kabupaten Lombok timur tahun pelajaran 2017/2018 dideskripsikan sebagai berikut: Hasil penelitian lompat jauh siswa kelas 5 SDN 1 Bungtiang. Tahun Pelajaran 2017/2018 saat pre-test, diperoleh nilai rata-rata $=1,591$ Sedangkan hasil posttest diperoleh nilai rata-rata $=2,063$ Hasil tersebut dapat dilihat pada tabel di bawah ini:

Tabel 1. Distribusi Frekuensi Hasil Lompat Jauh Pre-test dan post-test

\begin{tabular}{cccccc}
\hline No & Interval & $\begin{array}{c}\text { Frekueni } \\
\text { pretest }\end{array}$ & $\begin{array}{c}\text { Persentae } \\
\text { pretest }\end{array}$ & $\begin{array}{c}\text { Frekueni } \\
\text { post-test }\end{array}$ & $\begin{array}{c}\text { Persentae } \\
\text { post-test }\end{array}$ \\
\hline 1 & $1,50-1,65$ & 8 & 40 & 3 & 15 \\
2 & $1,66-1,81$ & 4 & 20 & 2 & 10 \\
3 & $1,82-1,97$ & 4 & 20 & 2 & 10 \\
4 & $1,98-2,13$ & 2 & 10 & 3 & 15 \\
5 & $2,14-2,29$ & 1 & 5 & 4 & 20 \\
6 & $2,30-2,45$ & 1 & 5 & 6 & 30 \\
\hline & Jumlah & 20 & 100 & 20 & 100 \\
\hline
\end{tabular}


Adapun bentuknya jika dilihat dalam bentuk diagram maka akan seperti pada gambar dibawah ini.

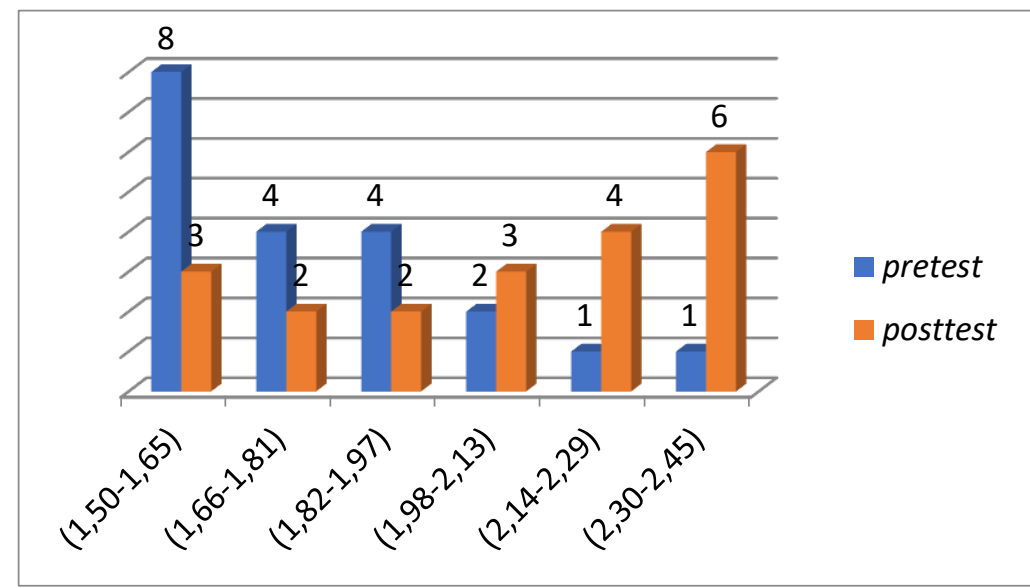

Grafik 1: Hasil penelitian pretest dan posttest lompat jauh

Berdasarkan gerafik 4.1 menunjukan bahwa ada perubahan hasil lompatan terdekat berdasarkan pretest dari 40\% menjadi $15 \%$ setelah diberikan treatmen pada saat post-test. Demikian halnya dengan prestasi lompatan terjauh pada pretest dan post-test mengalami peningkatan dari 5\% menjadi 30\%. Analisis data digunakan untuk menjawab hipotesis yang telah diajukan. Uji hipotesis menggunakan uji t.untuk memudahkan dalam pengolahan data, maka perlu di buat tabel persiapan berupa tabel kerja dan Hasil uji t dapat dilihat sebagai berikut:

Tabel 2. Hasil Lompat Jauh Pre-Test dan Post-Test

\begin{tabular}{cccccc}
\hline No & Nama & $\mathbf{X 1}$ & $\mathbf{X 2}$ & $\boldsymbol{D}_{\boldsymbol{X Z}-\boldsymbol{X 1}}$ & $\boldsymbol{D}^{\mathbf{2}}$ \\
\hline $\mathbf{1}$ & AN & 1,80 & 2,30 & 0,5 & 0,25 \\
$\mathbf{2}$ & ADP & 2,10 & 2,14 & 0,4 & 0,16 \\
$\mathbf{3}$ & AZI & 1,90 & 2,30 & 0,4 & 0.16 \\
$\mathbf{4}$ & AM & 1,70 & 1,65 & $-0,05$ & 0,0025 \\
$\mathbf{5}$ & AR & 1,30 & 1,66 & 0,36 & 0,1296 \\
$\mathbf{6}$ & BET & 1,30 & 2,16 & 0,86 & 0,7396 \\
$\mathbf{7}$ & DF & 1,65 & 2,30 & 0,65 & 0,4225 \\
$\mathbf{8}$ & MHH & 1,32 & 1,67 & 0,35 & 0,1225 \\
$\mathbf{9}$ & HYP & 1,30 & 1,52 & 0,22 & 0,484 \\
$\mathbf{1 0}$ & NP & 1,30 & 1,50 & 0,20 & 0,400 \\
$\mathbf{1 1}$ & NP & 1,31 & 2,14 & 0,83 & 0,6889 \\
$\mathbf{1 2}$ & LSA & 1,45 & 1,82 & 0,37 & 0,1369 \\
$\mathbf{1 3}$ & PA & 1,70 & 2,15 & 0,45 & 0,2025 \\
$\mathbf{1 4}$ & AAZ & 1,39 & 1,99 & 0,60 & 0,3600 \\
$\mathbf{1 5}$ & CMA & 1,60 & 2,30 & 0,70 & 0,4900 \\
$\mathbf{1 6}$ & MHN & 1,60 & 1,83 & 0,23 & 0,529 \\
$\mathbf{1 7}$ & MH & 1,50 & 1,99 & 0,49 & 0,2401 \\
$\mathbf{1 8}$ & EDA & 1,50 & 1,98 & 0,48 & 0,2304 \\
\hline
\end{tabular}




\begin{tabular}{cccccc}
\hline $\mathbf{1 9}$ & ZIN & 1,65 & 2,30 & 0,65 & 0,4225 \\
$\mathbf{2 0}$ & AS & 2,00 & 2,30 & 0,30 & 0,900 \\
& $\sum$ & 31,37 & 40 & 8,59 & 7,701 \\
\hline
\end{tabular}

Distribusi data ke dalam rumus t- test

$$
\begin{gathered}
t=\frac{\sum D}{\sqrt{\frac{N \cdot \sum D^{2}-\left(\sum D\right)^{2}}{(N-1)}}} \\
t=\frac{8,95}{\sqrt{\frac{20.7,071-73,7881}{(20-1)}}} \\
t=\frac{8,59}{\sqrt{\frac{67,6319}{19}}} \\
t=\frac{8,59}{\sqrt{3,5595}} \\
t=\frac{8,59}{1,8866} \\
t=4,553
\end{gathered}
$$

Berdasarkan hasil uji t tersebut diperoleh nilai $t$ hitung $(4,553)>t$ tabel $(1,729)$, dan nilai $p(0,00)<$ dari 0,05 , hal tersebut menunjukkan diartikan Ha: diterima dan Ho: ditolak. Jika Ha diterima maka hipotesisnya berbunyi "ada Pengaruh permainan tradisional engklek terhadap peningkatan kemampuan lompat jauh tanpa awalan pada sisiwa kelas 5 SDN 1 Bungtiang tahun 2017/2018.

\section{Simpulan}

Berdasarkan hasil analisis data dan pembahasan pada uraian sebelumnya telah diperoleh hasil uji t sebagai berikut : Nilai t hitung (4,553) > t tabel (1.729), hal tersebut menunjukkan Ha: diterima. Sehingga dapat disimpulkan bahwa ada Pengaruh permainan tradisional engklek terhadap peningkatan kemampuan lompat jauh tanpa awalan pada sisiwa kelas 5 SDN 1 Bungtiang tahun 2017/2018.

\section{Daftar Pustaka}

Fad, Aisyah. (2014). Kumpulan Permainan Anak Tradisional Indonesia: Cerdas Interaktif. Sugiyono. (2015). Metode Penelitian Pendidikan Kuantitatif dan Kualitatif. Bandung: Alfabeta.

Sukandarrumidi. (2012). Metodologi penelitian. Yogyakarta. Gajah Mada University Press. 